\title{
Community-based groundwater and ecosystem restoration in semi- arid north Rajasthan (2): reviving cultural meaning and value
}

Dr Mark Everard, University of the West of England (UWE), Coldharbour Lane, Frenchay Campus, Bristol BS16 1QY, UK (mark.everard@uwe.ac.uk, +44-(0)-7747120019).

\begin{abstract}
Cultural and other less directly exploited ecosystem services tend to be excluded from decision-making, yet may underlie strong ties between people and their surroundings providing significant incentives for engagement with ecosystem conservation. Overlooking non-marketed services leads to non-systemic, utilitarian understandings and narrow solutions. Aquatic species were recorded in eleven ponded sections of three sub-catchments in semi-arid north-east Rajasthan that had been regenerated through community-based management activities, along with local associated medicinal, spiritual and other cultural values. Local religious and traditional beliefs reinforce awareness of the co-dependence of people with nature. Socially held values may be incommensurable with quantification and monetisation methods applied to marketed services, other than by rough proxies, but can be significant in engendering engagement in landscape regeneration. Pervasive global declines in habitat quantity and quality, with their implications for human wellbeing through loss of ecosystem services, raise questions about the adequacy of interpretations of sustainable development that fail to recognise the need not merely to reduce pressures upon but to actively regenerate the supportive capacities of damaged ecosystems. Lessons from the study region can inform this global need for practical action and policy reform to restore ecosystems as fundamental resources underpinning continuing human security and opportunity.
\end{abstract}

\section{Keywords}

Ecosystem services, community-based management, water, regeneration, cultural, aquatic ecosystems

\section{Introduction}

The essence of the Ecosystem Approach is to fundamentally reframe human relationships with ecosystems through recognition of the diverse roles they play in underpinning multiple dimensions of wellbeing. Through twelve principles defined by the Convention on Biological Diversity, the Ecosystem Approach recognises interdependencies between humanity and ecosystems with which we co-evolved and co-exist (Convention on Biological Diversity, 2000 and 2010). The ecosystem services framework advanced by the Millennium Ecosystem Assessment (2005a) spans a broad range of often non-substitutable economic and non-economic values flowing to humanity from nature. 
Some of the more directly exploited services - provisioning services of food, fuel, fresh water and, increasingly, regulatory service of natural flood regulation - are recognised to different extents in established markets. However, externalities associated with their full production costs distort allocation of resources (Ayres and Kneese, 1969). Values for other less directly exploited services, including those associated with production of marketed services, are harder to quantify. This perpetuates their exclusion from decision-making at all scales, particularly supporting and some regulatory ecosystem services. It is commonly assumed that to value them is to double-count, as they constitute 'primary' and 'intermediate' services contributing to the production of more directly consumed and readily valued services (UK NEA, 2011). This view would be justified were supporting services (soil formation, nutrient cycling and habitat for wildlife) and regulatory services (climate (primarily carbon flux), flooding, disease transmission and soil erosion) fully internalised in market prices, for example for food and other farmed commodities. However, key messages of the Millennium Ecosystem Assessment (2005a), TEEB (2010a and 2010b), and national studies such as the UK National Ecosystem Assessment (UK NEA, 2011) highlight the substantial degradation of broad habitat types and their services through narrow exploitation for limited provisioning services. Agriculture is a principal driver of this globally declining trend (Millennium Ecosystem Assessment, 2005a and 2005b), highlighting the scale at which many services are excluded from markets with serious potential consequences.

Cultural benefits derived from nature have fared mixed fortunes. Exploitation of some habitats for recreation and tourism is highly valued financially (Sen et al., 2014), though exploitation of these benefits can also exert pressure on serviceproviding ecosystems (Halvorson and Davis, 1996). Some sites of spiritual and/or heritage value receive explicit protection, such as informal taboos surrounding Hindu temples and more formal designations such as qualifying features within World Heritage Sites and Biosphere Reserves. However, landscapes constantly change in response to shifting environmental conditions, land uses and policy priorities, such as the food sufficiency and associated land drainage agenda of post-Second World War Europe that substantially influenced landscape and service simplification. The diverse meanings attributed by different stakeholder groups are often poorly represented in decision-making, with immediate utilitarian values often dominating perceptions and ensuing decisions. A pervasive global example is the inundation of culturally meaningful sites through the filling of large dams, the resultant displacement of communities who do not share the benefits of dam development, and the sizeable constituencies whose livelihoods are affected by the changing character and services of host river systems (World Commission on Dams, 2000; Everard and Kataria, 2010; Everard, 2013). Where cultural and supporting services are overlooked or otherwise undervalued, degradation of ecosystems through narrow utilitarian uses undermines the physical health and socio-economic wellbeing of communities, their cultural identity and their long-term viability.

Nevertheless, there are examples around the world of community engagement in decision-making to revitalise formerly degraded ecosystems, with associated regeneration of linked ecological and socio-economic benefits. Everard (2015) analyses factors behind linked environmental and socio-economic regeneration across three catchments - the Arvari, Sarsa and Baghani - in a rural, semi-arid region in Alwar District, north-east Rajasthan (India). Here, community-led 
rehabilitation of catchment hydrology through reinstatement of locally adapted governance and physical monsoon run-off harvesting structures has promoted recharge of groundwater. This has in turn restored ecosystem services promoting socio-economic progress, reversing a history of socio-environmental degradation. Sinha et al. (2013) and Everard (2015) review changes in groundwater status, farmland productivity, characteristics of water harvesting structures (WHSs), reemergence of permanent surface water in rivers formerly dry outside of monsoon rainfall, and changes in landscape management in this region. These authors also address political factors behind the prior decline and how NGO community-level activism has driven the multi-decade recovery and rejuvenation of the linked socioecological system.

This paper, a partner to Everard (2015), extends consideration of the regeneration of these three catchments in Alwar District beyond restoration of the more utilitarian services supporting the recovery of rural livelihoods. This is important as 'cultural landscapes' - landscapes deliberately managed by humans (Schaich et al., 2010) are characterised by biodiversity and ecosystem services shaped by a complex, extended history of settlement and land use (Antrop, 1997 and 2005; Jones-Walters, 2008). The multiple culturally and socially rooted benefits provided by cultural landscapes create strong ties between humans and their natural surroundings, constituting amongst the strongest incentives for people to engage with environmental conservation yet often marginalised relative to more quantitatively assessed services (Schaich et al., 2010). Many ecosystem service studies fail to address cultural services as significant contributors to scheme success and net societal benefit, adding cultural and time depth to more spatially and quantitatively focused assessments (Tengberg et al., 2012). This study records findings from rapid ecological assessments of ponded sections within the three rejuvenated subcatchments in summer - the driest time of year - exploring medicinal, spiritual and other non-marketed aspects (as well as some domestic utilitarian uses that may be external to conventional markets) of restored aquatic taxa as a contribution to societal rejuvenation. Conclusions and transferrable lessons are derived.

\section{Methods}

Field research for this study was undertaken in March 2015, a hot and dry period with monsoon rains generally arriving in July. Rapid ecological assessments were undertaken in water bodies retained behind the eleven water management structures of different types and locations in the Arvari, Sarsa and Baghani catchments of Alwar District, Rajasthan (India), described by Everard (2015) with summary details of each water body in Annex 1 of this paper.

Rapid ecological assessments comprised recording of observations throughout a period of approximately 15 minutes of biota visible immersed, on the surface, emergent from or on the drawdown zone of the water body. Observations were made from the bankside or, where the water was not excessively deep or the banks too steep or friable, wading up to knee depth. All of the selected WHSs were constructed to promote retention and infiltration to groundwater of monsoon rainfall with associated wider environmental regeneration supporting and expanding human livelihoods, not primarily for nature conservation reasons. Nevertheless, the return 
of perennial water and soil moisture enabled colonisation by a range of wetland organisms, many of them obligate aquatic taxa.

For aquatic plants, no keys for the vicinity were available. However, the case study catchments drain into the Gangetic plain and, as recolonisation of regenerated water bodies was more likely from the adjacent and damper District of Bharatpur than from the more desert-dominated districts to the west of Alwar, the Illustrated Flora of Keoladeo National Park, Bharatpur, Rajathan: A general guide to the wetland flora of the Gangetic plains (Prasad et al., 1996) was perceived as the most relevant available guide, albeit not a recent publication. The Flora of Rajasthan (Sharma, 1989), Biodiversity of Ranthambhore Tiger Reserve, Rajasthan (Singh and Shrivastava, 2007) and also the website 'eFlora of India' (undated) served as additional sources. Only plants immersed or rooted in the water or rooted in adjacent drawdown zones were recorded at each site, seeking to maintain a distinction between aquatic flora and that encroaching from surrounding terrestrial habitats although noting that surveys included some invading terrestrial species (including a number of invasive, ruderal weeds). For fauna, Faunal Heritage of Rajasthan, India (Sharma et al., 2013) and Biodiversity of Ranthambhore Tiger Reserve, Rajasthan (Singh and Shrivastava, 2007) provided taxonomic guidance, with other species identified with the aid of the author's experience, local knowledge, online databases such as www. fishbase.org and, in the case of birds, corroboration with the Avibase bird checklist for Keoladeo National Park, Bharatpur (Lepage, 2015). Dr Rachna Chandra (Gujarat Institute of Desert Ecology) and Dr Damendra Kandal (Tigerwatch) also corroborated and helped with some species identifications.

Bias in selection of WHSs is acknowledged in terms of accessibility, the guidance of the NGO Tarun Bharat Sangh which had been instrumental in their creation, and limitations on time available to make visits. Taxonomic identification was also limited by the availability of keys, the mobility of species (small fish, frogs) evading sampling for identification using very basic equipment (observations, hand net, portable angling equipment where fish were evident), and also a bias towards species visible in daylight.

The cultural significance of species and taxonomic groups recorded in waterharvesting structures was deduced primarily by discussion with local people. Key correspondents included Rajendra Singh (founder of the NGO Tarun Bharat Sangh and qualified in Ayurvedic medicine), the headman of a local village (Rudmal Meena, headman of Harmeerpur), other members of Tarun Bharat Sangh, and experts in local NGOs (including Dr Dharmendra Khandal, Tigerwatch). Observations in Sharma et al. (2013) and other relevant literature in addition to internet searches linking taxa to medicinal uses and Hindu mythology and traditions were consulted to determine further meanings to local people.

\section{Results}

Annex 1 contains brief descriptions of the eleven WHSs, with lists of aquatic taxa observed at each during rapid ecological assessments. Further details of locations, uses and history of each site can be found in Everard (2015). Singh (pers. comm.) 
and Rudmal Meena (pers. comm.) report that these organisms have all naturally colonised the restored open surface water bodies.

Aquatic plants were most diverse at the Golakabass site ( 7 species), holding perennial water that was generally clear and in which small (unidentified) fish and several species of invertebrates were visible. Golakabass also supported the greatest diversity of birds (16 species). Some observed bird species are aquatic specialists (common kingfisher, little cormorant and pied kingfisher) though many other wetland species occurred as generalists in moist areas elsewhere across Rajasthan lacking open water (redshank, black-winged stilt and Indian pond heron) and many more were terrestrial species exploiting this habitat for drinking and other purposes (peacock, Eurasian collared dove, jungle babbler). At the other extreme, obligate aquatic plants were entirely absent from Chabutra Wala (CW), the agriculturally intense flat land behind a series of three anicuts across a shallow valley in the upper Sarsa catchment, and the johad by a road north of Gopalpura village (GP2) that held water but apparently was prone to drying out.

Table 1 summarises spiritual, medicinal and cultural meanings found to be associated with observed taxa in the sampled WHSs.

Table 1: Spiritual, medicinal and cultural meanings associated with observed taxa in sampled WHSs

\begin{tabular}{|c|c|}
\hline Species (and local name) & Uses and meanings \\
\hline \multicolumn{2}{|l|}{ Plant species } \\
\hline Ipomoea carnea & $\begin{array}{l}\text { - No Ayurvedic applications are reported for this an alien invasive } \\
\text { plant. However, diuretic, demulcent and aphrodisiac properties } \\
\text { are described for the native Indian Ipomoea digitata (La-Medicca, } \\
\text { undated) suggesting potential, as yet unexploited active } \\
\text { constituents in its non-native relative. Indeed, medicinal values } \\
\text { determined for Ipomoea carnea relate to a component identical to } \\
\text { marsilin, a sedative and anticonvulsant, and a glycosidic saponin } \\
\text { with anticarcinogenic and oxytoxic properties (Chand and Rohatgi, } \\
\text { 2005) } \\
\text { Diffuse submerged roots are recognised as helpful for water } \\
\text { purification }\end{array}$ \\
\hline Cyperus alopecuroides & $\begin{array}{l}\text { - Used locally as animal feed, and for making matting and hut roofs } \\
\text { - No Ayurvedic uses were recorded by interviewees, but extracts of } \\
\text { this plant have been found to have estrogenic properties } \\
\text { suggesting potential applications (Nassar et al., 2002) }\end{array}$ \\
\hline Scirpus littoralis & $\begin{array}{l}\text { - Used locally as animal feed, and for making matting and hut roofs } \\
\text { - No Ayurvedic uses were recorded for this species by interviewees } \\
\text { or literature search }\end{array}$ \\
\hline $\begin{array}{l}\text { Potamogeton pectinatus } \\
\text { Potamogeton crispus } \\
\text { Potamogeton nodosus } \\
\text { Utricularia spp. } \\
\text { Nitella spp. }\end{array}$ & $\begin{array}{l}\text { - All of these submerged aquatic macrophytes are used in Ayurvedic } \\
\text { practice for stomach health, particularly for stomach gases }\end{array}$ \\
\hline Polygonum spp. & $\begin{array}{l}\text { A prostrate, terrestrial plant with numerous axillary flowers, exploiting } \\
\text { the exposed soils of the drawdown zone }\end{array}$ \\
\hline
\end{tabular}




\begin{tabular}{|c|c|}
\hline & $\begin{array}{l}\text { - Reported by local communities to be used powdered in milk to } \\
\text { reduce body temperature }\end{array}$ \\
\hline Bergia ammannioides & $\begin{array}{l}\text { A terrestrial plant exploiting the drawdown zone } \\
\text { - Used only as animal fodder } \\
\text { - No Ayurvedic uses were recorded by interviewees, though } \\
\text { antibacterial, antioxidant and topical anti-inflammatory activities } \\
\text { are reported for the plant (Ezzat et al., 2016) }\end{array}$ \\
\hline Hydrilla verticillata & - A valued Ayurvedic medicine for stopping bleeding \\
\hline Solanum surattense & $\begin{array}{l}\text { An invasive terrestrial plant exploiting the drawdown zone } \\
\text { - Used for treatment of coughs, asthma, chest pains, sore throats } \\
\text { and toothache (Medplants, undated) }\end{array}$ \\
\hline Argemone mexicana & $\begin{array}{l}\text { An invasive terrestrial plant exploiting the drawdown zone } \\
\text { - Spiny, invasive ruderal weed, not perceived as useful }\end{array}$ \\
\hline Azolla pinnata & $\begin{array}{l}\text { - Boiled in water and used in Ayurvedic medicine to treat coughs } \\
\text { - Used locally as a fertiliser, as symbiotic cyanobacteria within this } \\
\text { floating fern fix nitrogen }\end{array}$ \\
\hline Typha angustata (patera) & $\begin{array}{l}\text { - Used for weaving of flooring and for thatching } \\
\text { - Astringent and diuretic properties of rhizome extracts are used in } \\
\text { Ayurvedic medicine (Ayurvedic Community, undated) }\end{array}$ \\
\hline Marsilea minuta & $\begin{array}{l}\text { Used as a vegetable as well as for a wide range of traditional } \\
\text { medicinal purposes, particularly cough and respiratory } \\
\text { problems, diarrhoea and skin diseases }\end{array}$ \\
\hline \multicolumn{2}{|r|}{ ( : } \\
\hline \multicolumn{2}{|c|}{$\begin{array}{l}\text { Generically, the diverse birds associated with water bodies serve important symbolic roles in culture, } \\
\text { religion, and in the dignity and livelihoods of local people. The holy bird Garuda is often assumed to } \\
\text { be an eagle, but is embodied in birds in general (Sharma et al., 2013). Birds are also generally } \\
\text { perceived as creating beauty and bringing happiness, as well as helping with agriculture. The song } \\
\text { and calls of birds creates a sense of life in the landscape. All birds have their special character and } \\
\text { meaning: specific meanings associated with just two species are outlined below. }\end{array}$} \\
\hline Pavo cristatus (peacock) & $\begin{array}{l}\text { - The peacock was the vahana (vehicle) of the God Karthikeya } \\
\text { (Sharma et al., 2013) } \\
\text { - Observing the display of the male peacock is seen as auspicious } \\
\text { - The peacock is an inspiration for traditional dances } \\
\text { - The call of the peacock is valued } \\
\text { - The peacock is associated with cultural dignity } \\
\text { - The peacock is a protected species, and also symbolic as the } \\
\text { national bird of India }\end{array}$ \\
\hline $\begin{array}{l}\text { Threskiornis } \\
\text { melanocephalus (black- } \\
\text { headed ibis or Oriental } \\
\text { white ibis, local name } \\
\text { 'cordateli') }\end{array}$ & $\begin{array}{l}\text { - Akin to the ibis in Egyptian mythology the form of the god Thoth } \\
\text { - The ibis is also perceived to take harmful things from the soil } \\
\text { - Black soils and black birds (in the case of this ibis black-headed) } \\
\text { have particular spiritual significance, which is interesting in the } \\
\text { light of the higher carbon content and blackness of wetland soils } \\
\text { and their associated biodiversity }\end{array}$ \\
\hline \multicolumn{2}{|l|}{ Vertebrates } \\
\hline Fishes & $\begin{array}{l}\text { - Little distinction is made between fish species, even between fish } \\
\text { as diverse as eels and other scaled fish. However, coarse } \\
\text { distinctions are sometimes made by lay people between more } \\
\text { obvious groups of fish such as 'bam' (the Hindi word for 'eel'), } \\
\text { 'chilwa' (a generic term for small fish) and 'rohu' (larger carps } \\
\text { though the rohu is technically a specific species Labeo rohita). }\end{array}$ \\
\hline
\end{tabular}




\begin{tabular}{|c|c|}
\hline & $\begin{array}{l}\text { - However, fish are commonly associated with temples, where they } \\
\text { are protected, revered and often tamed and fed at temple ghats } \\
\text { (steps to the water) for their Dharadi (connection with the gods) as } \\
\text { the god Vishnu took the form of the fish Matsya in his first } \\
\text { incarnation } \\
\text { - Fish have additional subsistence and economic values, where } \\
\text { harvested for consumption or trade (but not at least in theory } \\
\text { within sight of temples) } \\
\text { - Some species, such as murrel (snakeheads of the genus Channa), } \\
\text { are seen as purifying waters by predating on 'lesser' creatures } \\
\text { such as frogs, and therefore are an indicator of purification } \\
\text { processes to local people } \\
\text { - Although various species of fish and their parts are ascribed } \\
\text { medicinal values across the world (Everard, 2012), there is no } \\
\text { evidence of their use in this part of India perhaps related to the } \\
\text { taboo on harming them }\end{array}$ \\
\hline Reptiles: terrapins & $\begin{array}{l}\text { - In Hindu mythology, the world is thought to rest on the backs of } \\
\text { four elephants who stand on the shell of a turtle (there being little } \\
\text { distinction between terrapins, tortoises and turtles in Hindu } \\
\text { consciousness) } \\
\text { - The turtle is also a form of the God Kurmavtar (Sharma et al., 2013) } \\
\text { - The terrapin is seen as an indicator of rich and recovered } \\
\text { biodiversity, and the rediscovered prosperity of this region }\end{array}$ \\
\hline $\begin{array}{l}\text { Frogs, unidentified (local } \\
\text { name 'medek') }\end{array}$ & $\begin{array}{l}\text { - Singh (pers. Comm.) reports that frogs are generally seen locally as } \\
\text { common, simple and lacking any specific meaning } \\
\text { - Nevertheless, in Buddhist culture, frogs and toads are living } \\
\text { reminders of rain and fertility, transformation and rebirth, } \\
\text { including the return of the monsoon season (Khandro, undated) }\end{array}$ \\
\hline \multicolumn{2}{|l|}{ Invertebrates } \\
\hline $\begin{array}{l}\text { Water snails (Gastropoda), } \\
\text { various unidentified } \\
\text { species }\end{array}$ & $\begin{array}{l}\text { - The emergence out of the water of water snails during the } \\
\text { monsoon season is seen as symbolic of the completion of life cycles }\end{array}$ \\
\hline $\begin{array}{l}\text { Dragonflies (Odonata), } \\
\text { various unidentified } \\
\text { species }\end{array}$ & $\begin{array}{l}\text { - Dragonflies and damselflies are generally locally referred to as } \\
\text { 'helicopters', particularly by children } \\
\text { - No other specific meanings were identified }\end{array}$ \\
\hline Pond skaters (Gerridae) & $\begin{array}{l}\text { - No specific cultural or medicinal meanings were identified for this } \\
\text { group of animal through interviews or literature searches }\end{array}$ \\
\hline Waterboatmen (Corixidae) & $\begin{array}{l}\text { - No specific cultural or medicinal meanings were identified for this } \\
\text { group of animal through interviews or literature searches }\end{array}$ \\
\hline
\end{tabular}

\section{Discussion}

Defined as the non-material benefits that people obtain from ecosystems (Millennium Ecosystem Assessment, 2011a), assessment of trends in the status of, and benefits derived from, cultural ecosystem services inevitably entails a degree of subjectivity, diversity across stakeholder groups and different perspectives between disciplines (Milcu et al., 2013). These same factors can often result in the importance of these cultural services being overlooked or under-appreciated in more quantitatively based studies, despite their often critical importance to local people and hence in 
influencing scheme success (Gould et al., 2015). Culture has tended to be considered within ecosystem services analyses as a category of value that is separate from the material values of other ecosystem services (Chan et al. 2012; Satterfield et al., 2012; Satz et al. 2013). Although economic proxies, such as willingness to pay and travel cost analysis, provide a means to quantify some aspects of cultural valuation of an environmental setting (Church et al., 2011), the separation of cultural services into a discrete category by the Millennium Ecosystem Assessment (2011a) recognises that cultural value systems themselves may be incommensurable with utilitarian, monetary values. Defining culture as "... shared knowledge, values, and practices", Schnegg et al. (2014) used empirical analyses to shift the focus of cultural ecosystem services from experiences drawn from nature towards an analysis of processes that underlie the valuation of nature. Their research concluded that people perceive many places as providing multiple services, and that most of their valuations of ecosystem services are culturally shared. Culture shapes the ways in which nature is perceived and valued, and how these values are expressed (Gatzweiler and Hagedorn, 2013). A robust understanding of environmental values and their inclusion into decision-making and robust policy is essential as fundamental drivers of behaviour and management practices (Kalof and Satterfield, 2005). Given the commonly incommensurable nature of socially held values with monetisation, cultural ecosystem services constitute an important social lens for recognition of multiple, less tangible and culturally relative benefits provided by natural systems. These non-material cultural values may be of great significance due to the strength of ties they create between humans and their natural surroundings, constituting amongst the strongest incentives for people to get involved with environmental conservation (Schaich et al., 2010) and often forming a key determinant of scheme success (Gould et al., 2015).

The affinity between people and nature in Indian culture has deep roots, dating back into ancient times when the natural environment was considered a creation of Lord Brahma, the creator, with human cycles of life and death linked to natural cycles (Singh, 2005). In Hindu beliefs, Brahman, the spirit of the creator Brahma, is the source of all things and is therefore within all things, including all people and all of the natural world (for example as articulated in the Advaita Vedanta, an Upanishad, or holy book, of the Vedic religion). Consequently, many animals, most famously the 'scared cow' but also for example the monkey god Hanuman and the elephant god Ganesh, have become objects of worship. Most Hindu Gods and Goddesses have some animal as their vahana, or vehicle (Sharma et al., 2013). Trees too have been objectives of worship. These include the Peepal tree (Ficus religiosa) particularly during the Harappan (Indus Valley) civilisation founded in approximately 3,000 BC, the 'Strangler Fig' (a common name for a number of tropical and subtropical plant species including some Indian banyans - several epiphytic Ficus species - and unrelated vines) and Dev Vani (sacred groves of trees), and also the Chabutra which is a traditional circular parapet built around a tree trunk (typically an Acacia or Peepal) for village elders to sit and discuss important matters or for evening gatherings.

Hindu scriptures relate to humanity returning from its descent into hedonism back into a state of greater sympathy with nature (Singh, 2005). The relationship between Indian religious traditions and aquatic ecosystems is seen in the common occurrence of ghats, or steps to the water's edge, in riparian temples, where people and fish 
commonly interact. The harming or killing of fish and other wildlife in proximity to Hindu temples is prohibited, which can render these sites valuable for nature conservation including the abundance and diversity of fish species (Vyas et al., 2012). A desert village in Rajasthan was also the home of Guru Jambheshwarji, now commonly referred to as the 'environmental saint' who, more than 500 years ago, founded the Bishnoi religion in which the Guru exhorted people to stop worshipping idols and instead respect and protect the environment by considering animals and plants as God's creations (Sharma et al., 2013). The regional pervasion of these religious underpinnings of Indian culture are revealed in data from the 2011 Indian census (Government of India, 2011), which finds that $78.35 \%$ of the national population of India practices Hinduism, 1.9\% Sikhism and $0.4 \%$ Jainism, with generally higher proportions of $88.8 \%, 1.4 \%$ and $1.2 \%$ in Rajasthan. (A more localised analysis for Alwar District from 2011 Indian census data is planned but was not published at the time of writing.) Despite the evident rising pressures of consumerist lifestyles, this cultural underpinning is significant in shaping how the diversity of people of different cultural and religious persuasions value ecosystems and their services.

The linked socio-environmental regeneration reviewed by Everard (2015) took account of the impressive scale and extent or socio-economic recovery achieved through regeneration of catchment ecosystems. However, the metrics observed (groundwater levels, cropping, forest cover, income, population, etc.) were largely utilitarian and largely omitted the recovery of biota with deeper if less tangible cultural meaning. Although no published survey data are available, it can be assumed that aquatic taxa were severely diminished as key water-dependent constituents of formerly degraded catchment ecosystems. Allied with socioeconomic degradation, there will also inevitably have been a commensurate degradation of societal values beyond the purely utilitarian (provision of water, food, fuel, tradable goods, etc.), also including the medicinal, spiritual and other cultural meanings associated with degraded species and habitats, in addition to their roles as indicators of ecosystem functioning.

Although the survey of aquatic species was selective in terms of location, the limitations of sampling methods and identification keys, it is clear from the tables in Annex 1 that a wide range of aquatic taxa had recovered in the sampled WHSs. These surveys highlight the presence of many obligate aquatic plants and animals in river systems once dry throughout much of the year. No rare species were identified, but this was an expected outcome as most of the obligate aquatic organisms will have had to reinvade the river system following hydrological regeneration from 'island' and other adjacent populations. However, most recovering aquatic species across taxa have some form of meaning beyond their purely utilitarian applications, highlighting additional societal enrichment which, if elusive in terms of established monetisation measures, is important from a cultural perspective and in meeting local, non-marketed needs. The significance of this cultural connection with aquatic ecosystems and taxa is exemplified by the ghats associated with riparian Hindu temples, as for example observed at the Tilda site where an abundance of the cyprinid fish Systomus sarana was observed. During the time of the research visit, local people - particularly children - were swimming and interacting freely with these fish in the impoundment. Whilst interested in and permitting our sampling method (capture by rod and line), these people were 
concerned that all fish caught for identification were returned alive and unharmed to the water in line with their religious beliefs. The children were also keen to show us other wildlife, including the 'helicopters' (a red darter species) common around the water body, revealing a close interest in nature.

Sinha et al. (2013), Everard (2015) and Singh (pers. Comm.), endorsed by discussions with local people (significantly including Rudmal Meena, headman of Harmeerpur village), report that a village elder prompted the initial focus of the NGO Tarun Bharat Sangh (TBS) on regeneration of the water system as a basis for rejuvenation of the wider ecosystem and the many benefits that it would provide to people. This focus on the water system and the progressive acceptance by local people that measures to restore hydrology would lead to enhanced productivity, security and a range of linked societal benefits, captures some of the essence of what is increasingly being referred to as an 'anchor service'. (Sensu Everard, 2014, an 'anchor service comprises a focal ecosystem service perceived as a priority benefit or policy need that, if not addressed purely in isolation, can constitute an 'anchor service' around which management can be planned for optimal co-delivery of a range of linked ecosystem service benefits.) Natural and managed ecosystems do not deliver single services in isolation, but generate suites of linked 'environmental services' (sensu Schomers and Matzdorf, 2013) of greater cumulative societal benefit. It is uncertain to what extent the broader Indian cultural psyche relating to the interdependence of humanity with nature and its processes currently underpins aspirations to realise multiple dimensions of societal benefit from ecosystem management. However, the Gandhian ethos behind TBS interventions includes participation, equity and decentralisation, self-sufficiency and mutual aid, and explicitly recognises that the needs of people are linked to the vitality of the ecosystems that support them. Recognition of the multiplicity of benefits - those that can be more readily quantified and monetised but also those that are more deeply held and less readily measured and valued financially - is important for engaging all interests in society in collectively beneficial interventions.

Community and livelihood aspects of sub-global assessments of the Millennium Ecosystem Assessment were reviewed by Folke et al. (2005), drawing out key messages of relevance to the case study in this paper. Amongst these key messages were that community-based assessments are necessary components of multiscale assessments as they capture the real-life, human-scale experiences of changes in ecosystems and human wellbeing. They also provide information about existing management systems and values implicit in cultural landscapes and associated ecosystem services, highlighting processes, patterns, knowledge, 'lumpiness' (uneven distribution in space and time) and complexities that would not otherwise be evident from top-down 'expert' assessment alone. Furthermore, local communities are not mere spectators, but are active participants in and managers of ecosystems and their capacities to deliver services. Diversity in ecosystems is important in reducing the vulnerability of communities. In this regard, the spiritual and cultural values of ecosystems are as important as other more immediately exploitable services for many local communities, providing a sense of place and identity, aesthetic and recreational values, all of which engender caretaking and custodianship that can contribute to ecosystem resilience and restoration.

Furthermore, collaboration across scales that includes community-held values, perspectives and needs is of great importance for improving the coherence of 
ecosystem management and human wellbeing, as evidenced in the study location by the cumulative efforts of local communities combining to regenerate ecosystem integrity and functioning across whole catchments and thereby to increase water, food and livelihood security.

Linked socio-ecological degradation is, regrettably, a phenomenon observed widely across the world. Examples of linked nature-society degradation include those associated with the retreat of the Aral Sea (White, 2013) and the interdependent links between poverty and soil erosion in developing countries (Ananda and Herath, 2003). So the regeneration of linked ecological and socio-economic value achieved in these catchments in Alwar district serves as an exemplar that may inform reversal of linked socio-environmental degradation elsewhere in the world. Similar reversals of prior cycles of linked ecological and socio-economic degradation have been achieved through community participation in localities as diverse as China's Loess Plateau (Chen et al., 2007; World Bank, 2007; Feng et al., 2013) and areas of the Ethiopian uplands (Chadhokar and Abate, 1988; Nyssen, 1997; Mekuria et al., 2011). Rehabilitation of ecosystems and their services as a basis for socioeconomic regeneration may become a more prevalent need across both the developing and the already-developed worlds, as the burgeoning needs of a growing global human population and declining climatic stability compound pressures on the ecosystems that provide society with fundamental resources and underpin continuing human security and opportunity.

A feature shared by these examples of linked socio-environmental regeneration is connection across scales, with outcomes for large-scale ecosystems (catchments, upland areas) shaped by the interaction of multiple self-beneficial, community-scale interventions: a form of 'pervasive localism' rather than resultant from monolithic, top-down policy imposition. This observation is consistent with the findings of Folke et al. (2005), particularly with regard to connection with the real-life experiences of local people, their role as active managers, the importance to them of less tangible spiritual and cultural values, and collaboration across scales. One of the common critiques of the wider formal and informal policy environment, particularly in the already-developed world, is that markets, statutory legislation, common/civil law, market-based instruments and protocols, etc., have evolved as a fragmented set of incentives and constraints influencing the freedoms of resource owners and managers (Everard, 2011; Everard et al., 2014). Across this fragmented policy environment, rewards are often strongly biased towards single, utilitarian outcomes generally related to prioritised production of provisioning ecosystem services, albeit occasionally making allowances for impacts such as through subsidies for waterand wildlife-sensitive farming or culturally valued sites or landscapes, but in a manner that is inconsistent with safeguarding the breadth of ecosystem services of optimal benefit to society. Whilst this contributes to the production of mosaic landscapes, reflecting both natural conditions and landowner aspirations, there is a pronounced tendency towards maximisation of narrow, short-term benefits particularly farmed production - at the net expense of ecosystem integrity, functioning and resilience and breadth of service provision (Everard et al., 2014). In arid and semi-arid, erosive and other vulnerable landscapes, this can rapidly accelerate into cycles of linked socio-environmental degradation, as observed widely across the world particularly in the spread of desertification. 
Local-scale decision-making and resource stewardship can make significant differences at landscape scale. The bottom-up rebuilding of resilience and carrying capacity from village to sub-catchment, catchment and higher scales, consistent with needs and stated aspirations and stated commitments at international, national and regional scales, depends on a more nuanced policy environment that better rewards, or permits, landscape management in which optimisation of outcomes across a range of ecosystem services is the goal rather than exploitation of a subset of utilitarian benefits with many unintended externalities. As the quality and character of larger-scale ecosystems are in reality determined by networks of linked local-scale socio-ecological systems, environmental governance and poverty alleviation initiatives need to evolve to ensure greater consistency between high-level intent and local-scale, self-beneficial contributory interventions. Local benefits are best attained through local involvement in governance and, importantly, the inclusion of a plurality of values provided by ecosystems within deliberation and decision-making processes. The role of the state does not diminish, but shifts from 'state as provider' to 'state as enabler' as has been observed as a trend across multiple policy areas (United Nations Centre for Human Settlements (HABITAT), 1996).

Taking account of cultural context and associated, often highly localised cultural values is vital in decision-making that represents the needs and perspectives, and elicits the support, of local people who are at the root of community-based solutions. These solutions, providing benefits at both local as well as broader landscape scales, constitute a kind of 'pervasive localism' that can optimally regenerate tightly linked socio-ecological systems, increasing their capacities, potential to support human wellbeing and resilience. In the light of pervasive global declines in habitat quality and ecosystem services and their adverse implications for continuing human security and wellbeing (Millennium Ecosystem Assessment, 2011a), it is questionable whether approaches to sustainable development that seek merely to reduce pressure on a declining baseline of ecosystem health and extent are sufficient. Rather, active engagement in regeneration of damaged ecosystems, not merely in the developing world but across the already-developed world, is essential if the supportive capacities and contribution to continuing human wellbeing of ecosystems at all scales are to be assured.

This research reveals three further priority research needs. Firstly, linguistics and other resource limitations mean that assessment of non-market benefits in the target catchments was based on expert opinion of observed regenerated biodiversity, whereas greater insight could have been deduced were it possible to interview a wider cross-section of local residents. Secondly, characterisation of precisely how the policy environment could be constructively reformed, such that local solutions could be derived in synergy with the top-down policy environment rather than in defiance of it (as discussed in more detail by Everard , 2015), would be instructive both for policy-makers and local communities. Thirdly, improved characterisation of the principles underpinning regenerative, community-based socio-environmental outcomes would enable the more effective upscaling and outscaling of 'lessons learned' to be applied elsewhere in Rajasthan, India and to other similarly vulnerable landscapes.

\section{Conclusions}


The generally incommensurable nature of socially held values, often themselves shaped by local context, with the kinds of quantification and monetisation applied to marketed services means that they tend to be excluded from evaluation and decision-making. However, diverse non-market values are often significant in defining relationships between people and their natural surroundings. Biodiversity observed in water bodies within the three regenerated catchments in Rajasthan carries a range of non-market medicinal, spiritual and traditional meanings for local people, as well as supporting local uses that may be external to markets. These services represent not merely an often uncounted set of benefits arising from ecosystem rehabilitation, but also a significant incentive for local beneficiaries to engage in resource conservation and regenerative management measures. Given pervasive global declines in ecosystem health, and its adverse implications for human wellbeing, a vision of sustainable development that fails to recognise the need for regeneration of the supportive capacities of damaged ecosystems may now be insufficient. More complete accounting for the breadth of benefits accruing to people from ecosystems is essential for systemic assessment and sustainable management solutions, a significant part of which is the inclusion of formerly overlooked constituencies and their non-utilitarian as well as utilitarian perspectives. Systemic assessment and recognition of multiple ecosystem service value systems in decision-making is essential for inspiring community-based, socio-environmentally regenerative management.

\section{Acknowledgements}

Many thanks to Dr Rachna Chandra (Gujarat Institute of Desert Ecology) and Dr Dhamendra Khandal (Tigerwatch) for corroborating and otherwise helping with some species identifications. My thanks also to my colleagues Dr Nevil Quinn and Dr Natasha Constant at the University of the West of England (UWE Bristol) for their critical review and insights in drafts of this paper. Elements of fieldwork were supported with core funding from the University of the West of England, with the support of Professor Jackie Rogers and Professor Chad Staddon.

\section{References}

Ananda, J. and Herath, G. (2003). Soil erosion in developing countries: a socioeconomic appraisal. Journal of Environmental Management, 68(4), pp.343-53.

Antrop, M. (1997). The concept of traditional landscapes as a base for landscape evaluation and planning: the example of Flanders Region. Landscape and Urban Planning, 38, pp.105-117.

Antrop, M. (2005). Why landscapes of the past are important for the future. Landscape and Urban Planning, 70(1-2), pp.21-34.

Ayres, R.U. and Kneese, A.V. (1969). Production, consumption, and externalities. The American Economic Review, 59(3), pp.282-297. 
Ayurvedic Community. (undated). Typha angustata.

http://www.ayurvediccommunity.com/Botany.asp?Botname=Typha\%20angustata.

Government of India. (2011). Indian census 2011. Government of India, Ministry of Home Affairs. www.censusindia.gov.in (accessed $23^{\text {rd }}$ April 2015).

Nyssen, J. (1997). Vegetation and soil erosion in Dega Tembien (Tigray, Ethiopia). Bull. Jard. Bot. Nat. Belg./Bull. Nat. Plantentuin Belg., 66, pp.39-62

Chadhokar, P. and Abate, S. (1988). Importance of revegetation in soil conservation in Ethiopia. Pages 1203-1213. In: Rimwanich, editor. Constraints and solutions to application of conservation practices. Bangkok, Thailand.

Chan, K. M. A., T. Satterfield, and J. Goldstein. (2012). Rethinking ecosystem services to better address and navigate cultural values. Ecological Economics, 74, pp.8-18.

Chand, N. and Rohatgi, P. K. (2005). Impact toughness of Ipomoea carnea particulate-polyester composite. Journal of Materials Science Letters, 6(6), pp.695697.

Chen, L., Huang, Z., Gong, J., Fu, B. and Huang, Y. (2007). The effect of land cover/vegetation on soil water dynamic in the hilly area of the loess plateau, China. Catena, 70(2), pp.200-208.

Church, A., J. Burgess, N. Ravenscroft, W. Bird, K. Blackstock, E. Brady, M. Crang, R. Fish, P. Gruffudd, S. Mourato, J. Pretty, D. Tolia-Kelly, K. Turner, and M. Winter. 2011. Cultural services. Pp.633-691 in United Kingdom National Ecosystem Assessment, editor. The UK national ecosystem assessment technical report. United Nations Environment Programme-World Conservation Monitoring Centre (UNEPWCMC, Cambridge, UK. [online] URL: http://uknea.unep-wcmc.org/

Convention on Biological Diversity. (2000). Ecosystem Approach. UNEP/CBD COP5 Decision V/6 (http://www.cbd.int/decision/cop/?id=7148 , accessed $22^{\text {nd }}$ April 2015).

Convention on Biological Diversity. (2010). Operational guidance for application of the ecosystem approach (http://www.cbd.int/ecosystem/operational.shtml, accessed $22^{\text {nd }}$ April 2015).

eFlora of India. (undated). eFlora of India.

(https://sites.google.com/site/efloraofindial, accessed 24 ${ }^{\text {th }}$ April 2016.)

Everard, M. (2011). Common Ground: The Sharing of Land and Landscapes for Sustainability. Zed Books, London. 214pp.

Everard, M. (2012). Fantastic Fishes: A Feast of Facts and Fables. Ellesmere: Medlar Press.

Everard, M. (2013). The Hydropolitics of Dams: Engineering or Ecosystems? Zed Books, London. 
Everard, M. (2014). Nature's marketplace. The Environmentalist, March 2014, pp.2123.

Everard, M., Dick, J., Kendall, H., Smith, R.I., Slee, R.W, Couldrick, L., Scott, M. and MacDonald, C. (2014). Improving coherence of ecosystem service provision between scales. Ecosystem Services, 9, pp.66-74. DOI:

10.1016/j.ecoser.2014.04.006.

Everard, M. and Kataria, G. (2010). The proposed Pancheshwar Dam, India/Nepal: A preliminary ecosystem services assessment of likely outcomes. An IES research report. The Institution of Environmental Sciences, London. https://www.theies.org/resources/proposed-pancheshwar-dam (accessed 23rd April 2015).

Everard, M. (2015). Community-based groundwater and ecosystem restoration in semi-arid north Rajasthan (1): socio-economic progress and lessons for groundwater-dependent areas. Ecosystem Services, 16, pp.125-135.

Ezzat, S.M., Choucry, M.A. and Kandil, Z.A. (2016). Antibacterial, antioxidant, and topical anti-inflammatory activities of Bergia ammannioides: A wound-healing plant. Pharmaceutical Biology, 54(2), pp.215-24.

Feng, X., Fu, B., Lu, N., Zeng, Y. and Wu, B. (2013). How ecological restoration alters ecosystem services: an analysis of carbon sequestration in China's Loess Plateau. Scientific Reports, 3. No.2846. doi:10.1038/srep02846.

Folke, C., Fabricius, C., Cundill, G., Schultz, L., Queiroz, C., Gokhale, Y., Marín, A., Camac-Ramirez, E., Chandola, S., Ahmed, M.T., Talukdar, B., Argumedo, A. and Torres, F.C. (2005). Chapter 11: Communities, Ecosystems, and Livelihoods. In: by Capistrano, D., Samper, C., Lee, M.J. and Raudsepp-Hearne, C. (Eds.) Ecosystems and Human Well-Being: Findings of the Sub-Global Assessments Working Group v. 4: Multiscale Assessments (Millennium Ecosystem Assessment). Island Press, Washington D.C.

Gatzweiler, F.W. and Hagedorn, K. (2013). Biodiversity and Cultural Ecosystem Services. Encyclopedia of Biodiversity (Second Edition), pp.332-340. doi:10.1016/B978-0-12-384719-5.00423-8.

Gould, R.K., Klain, S.C., Ardoin, N.M., Satterfield, T., Woodside, U., Hannahs, N., Daily, G.C. and Chan, K.M. (2015). A protocol for eliciting nonmaterial values through a cultural ecosystem services frame. Conservation Biology, 29(2), pp.575586.

Halvorson, W.L. and Davis, G.E. (1996). Science and Ecosystem Management in the National Parks. The University of Arizona Press, Tucson.

Jones-Walters, L. (2008). Biodiversity in multifunctional landscapes. Journal for Nature Conservation, 16, pp.117-119. 
Kalof, L. and Satterfield, T. (2005). The Earthscan Reader in Environmental Values (Earthscan Reader Series). Earthscan, Abingdon.

Khandro. (undated). Frog and toad. http://www.khandro.net/animal frogs.htm.

La-Medicca. (undated). Ipomoea digitata. http://www.la-medicca.com/raw-herbsIpomoea-digitata.html.

Lepage, D. (2015). Avibase bird checklist for Keoladeo National Park, Bharatpur. http://avibase.bsc-eoc.org/checklist.jsp?region=INnwrj01\&list=howardmoore.

Medplants. (undated). Solanum surattense / xanthocarpum, Kantakari, Kandankattiri. http://medplants.blogspot.co.uk/search/label/Solanum\%20surattense.

Mekuria, W., Veldkamp, E., Tilahun, M. and Olschewski, R. (2011). Economic valuation of land restoration: The case of exclosures established on communal grazing lands in Tigray, Ethiopia. Land Degradation and Development, 22(3), pp. 334-344. DOI: 10.1002/ldr.1001.

Milcu, A.I., Hanspach, J., Abson, D.J. and Fischer, J. (2013). Cultural ecosystem services: a literature review and prospects for future research. Ecology and Society, 18(3), pp.44.

Millennium Ecosystem Assessment. (2005a). Ecosystems and Human Well-being. Washington DC: Island Press.

Millennium Ecosystem Assessment. (2005b). Ecosystems and Human Well-being: Wetlands and Water Synthesis. World Resources Institute, Washington, DC.

Nassar, M.I., Abdel-Razik, A.F., El-Khrisy, E.E-D.A.M., Dawidarb, A-A. M., Bystrom, A. and Mabry, T.J. (2002). A benzoquinone and flavonoids from Cyperus alopecuroides. Phytochemistry, 60(4), pp.385-387.

Nyssen, J. (1997). Vegetation and soil erosion in Dega Tembien (Tigray, Ethiopia). Bull. Jard. Bot. Nat. Belg./Bull. Nat. Plantentuin Belg., 66, pp.39-62

Prasad, V.P., Mason, D., Marburger, J.E. and Ajith Kumar, C.R. (1996). Illustrated Flora of Keoladeo National Park, Bharatpur, Rajathan: A general guide to the wetland flora of thee Gangetic plains. Oxford University Press, Oxford and Bombay.

Satterfield, X. Basurto, A. Bostrom, R. Chuenpagdee, R., Gould, B. S. Halpern, N. Hannahs, J. Levine, B. Norton, M. Ruckelshaus, R. Russell, J. Tam, and U. Woodside. (2012). Where are cultural and social in ecosystem services? A framework for constructive engagement. BioScience, 62, pp.744-756.

Satz, D., R. K. Gould, K. M. A. Chan, A. Guerry, B. Norton, T., Satterfield, B. S. Halpern, J. Levine, U. Woodside, N. Hannahs, X. Basurto, and S. Klain. (2013). The challenges of incorporating cultural ecosystem services into environmental assessment. Ambio, 42, pp.675-684. 
Schaich, H., Bieling, C. and Plieninger, T. (2010). Linking Ecosystem Services with Cultural Landscape Research. GAIA, 19(4), pp.269 - 277.

Schnegg, M., Rieprich, R. and Pröpper, M. (2014). Culture, Nature, and the Valuation of Ecosystem Services in Northern Namibia. Ecology and Society 19(4), p.26. http://dx.doi.org/10.5751/ES-06896-190426

Schomers, S. and Matzdorf, B. (2013). Payments for ecosystem services: a review and comparison of developing and industrialized countries. Ecosystem Services, 6, 16-30. DOI: 10.1016/j.ecoser.2013.01.002i.

Sen, A., Harwood, A.R., Bateman, I.J., Munday, P., Crowe, A., Brander, L., Raychaudhuri, J., Lovett, A.A., Foden, J. and Provins, A. (2014). Economic Assessment of the Recreational Value of Ecosystems: Methodological Development and National and Local Application. Environmental and Resource Economics, 57(2), pp.233-249.

Sharma, B.K., Kulshreshtha, S. and Sharma, S. (2013). Historical, sociocultural, and mythological aspects of faunal conservation in Rajasthan. In: B.K. Sharma, S, Kulshreshtha and A.R. Rahmani (eds). Faunal Heritage of Rajasthan, India: General Background and Ecology of Vertebrates, Volume 1. Springer: New York.

Sharma, S. The Flora of Rajasthan. Scientific Publishers, Jodhpur.

Sharma, K.K. (1989). The Flora of Rajasthan. Scientific Publishers, Jodhpur.

Singh, R. (2005). Environmental conservation and Indian consciousness. Tarun Bharat Sangh, Alwar.

Singh, V. and Shrivastava, A.K. (2007). Biodiversity of Ranthambhore Tiger Reserve, Rajasthan. Scientific Publishers (India), Jodhpur.

Sinha, J., Sinha, M.K. and Adapa, U.R. (2013). Flow - River Rejuvenation in India: Impact of Tarun Bharat Sangh's Work - SIDA Decentralised Evaluation 2013:28. Swedish International Development Cooperation Agency, Stockholm. http://www.sida.se/English/publications/Publication database/Publications-byyear/2013/november/Flow-8211-River-Rejuvenation-in-India-Impact-of-TarunBharat-Sangh8217s-work/ (accessed 23 ${ }^{\text {rd }}$ April 2015).

TEEB. (2010a). The Economics of Ecosystems and Biodiversity Ecological and Economic Foundations. Edited by Pushpam Kumar. Earthscan, London and Washington.

TEEB. (2010b). The Economics of Ecosystems and Biodiversity: Mainstreaming the Economics of Nature: A Synthesis of the Approach, Conclusions and Recommendations of TEEB. Earthscan, London and Washington.

Tengberg, A., Fredholm, S. Eliasson, I., Knez, I., Saltzman, K. and Wetterberg, O. (2012). Cultural ecosystem services provided by landscapes: assessment of heritage values and identity. Ecosystem Services, 2, pp.14-26. 
UK NEA. (2011). The UK National Ecosystem Assessment: Synthesis of the Key Findings. UNEP-WCMC, Cambridge (http://uknea.unep-wcmc.org/, accessed $10^{\text {th }}$ April 2015).

United Nations Centre for Human Settlements (HABITAT). (1996). An Urbanizing World: Global Report on Human Settlements. Oxford University Press.

Vyas, V., Damde, D. and Parashar, V. (2012). Fish biodiversity of Betwa River in Madhya Pradesh, India with special reference to a sacred ghat. International Journal of Biodiversity and Conservation, 4(2), pp.71-77.

White, K.D. (2013). Nature-society linkages in the Aral Sea region. Journal of Eurasian Studies, 4(1), pp.18-33.

World Bank. (2007). Restoring China's Loess Plateau. World Bank, New York.

World Commission on Dams. (2000). Dams and Development: A New Framework for Better Decision-making. Earthscan, London. 


\section{Annex 1: Summary description and observed aquatic taxa in WHSs}

The series of Tables below contains a brief description of the eleven WHS for which rapid ecological assessments were conducted. Further details of locations, uses and history of each site can be found in Everard (2015). Singh (pers. comm.) and Rudmal Meena (pers. comm.) report that these organisms have all naturally colonised the restored open surface water bodies.

\section{Beechkharaga (BE): Sarsa catchment}

Beechkharaga $\left(27.249158^{\circ} \mathrm{N}, 76.30568^{\circ} \mathrm{E}, 403\right.$ metres altitude), a newly-completed johad (semicircular bund detaining monsoon run-off enabling it to recharge groundwater) near Jaitpur village in the upper Sarsa catchment. The johad was yet to receive rainfall at the time of the site visit.

\begin{tabular}{|c|l|l|}
\hline \multicolumn{2}{|l|}{ Aquatic plant species } & Other aquatic taxa \\
\hline $\begin{array}{l}\text { None (newly-built johad encompassing only } \\
\text { dryland species prior to monsoon filling) }\end{array}$ & $\begin{array}{l}\text { None (newly-built johad encompassing only } \\
\text { dryland species prior to monsoon filling) }\end{array}$ \\
\hline
\end{tabular}

\section{Gopalpura (GP1): Sarsa catchment}

Gopalpura $\left(27.268606^{\circ} \mathrm{N}, 76.30753^{\circ} \mathrm{E}, 407\right.$ metres altitude, $882 \mathrm{~m}^{2}$ area), a small cresent-shaped johad built in 1985 in the upper Sarsa catchment holding water all year to recharge groundwater and also used extensively for stock watering.

\begin{tabular}{|l|l|}
\hline Aquatic plant species & Other aquatic taxa \\
\hline POLYGONACEAE & FISHES \\
Polygonum spp., A prostrate, terrestrial plant & $\bullet \quad$ Very small unidentified fish species \\
with numerous axillary flowers, exploiting the & BIRDS \\
exposed soils of the drawdown zone & $\bullet \quad$ Pale martin (Riparia diluta) \\
Other vegetation in johad is not aquatic but & AMPHIBIANS \\
comprises two ruderal weeds & $\begin{array}{l}\text { Unidentified small frog species } \\
\text { PAPAVERACEAE }\end{array}$ \\
$\begin{array}{l}\text { INSECTS } \\
\text { SOLANACEAE }\end{array}$ & Red-colours darters (small dragonflies of \\
- Solanum surattense & \\
\hline
\end{tabular}

\section{Chabutra Wala (CW): Sarsa catchment}

Chabutra Wala $\left(27.270369^{\circ} \mathrm{N}, 76.310328^{\circ} \mathrm{E}, 408\right.$ metres altitude) is a series of three anicuts with water level control sluices built in 1985 across a shallow valley in the upper Sarsa catchment to retain monsoon run-off, fertilising soils and regenerating groundwater enabling production of multiple crops per year.

\begin{tabular}{|l|l|}
\hline Aquatic plant species & Other aquatic taxa \\
\hline - No aquatic plants present (though several & $\bullet \quad \begin{array}{l}\text { Diverse, mainly terrestrial bird and insect } \\
\text { species observed using farmed land }\end{array}$ \\
$\begin{array}{l}\text { wetland-adapted, erect species of } \\
\text { Polygonum and other taxa present) as open } \\
\text { water is not present all year and the land is } \\
\text { used extensively for cropping }\end{array}$ & \\
\hline
\end{tabular}

\section{Johad by road north of Gopalpura (GP2): Sarsa catchment}

Johad on sloping land by road north of Gopalpura village $\left(27.276656^{\circ} \mathrm{N}, 76.302532^{\circ} \mathrm{E}, 411\right.$ metres 
altitude, $816 \mathrm{~m}^{2}$ area), recharging groundwater and used for watering stock but apparently drying down in full summer.

\begin{tabular}{|l|c|}
\hline Aquatic plant species & Other aquatic taxa \\
\hline $\begin{array}{l}\text { No aquatic plants present as water body } \\
\text { may not be permanent, and is heavily } \\
\text { trampled and grazed by stock }\end{array}$ & $\bullet \begin{array}{l}\text { Large unidentified raptor drinking at } \\
\text { water's edge on arrival }\end{array}$ \\
\hline
\end{tabular}

\section{Golakabass (GK): Sarsa catchment}

Golakabass $\left(27.10133^{\circ} \mathrm{N}, 76.321519^{\circ} \mathrm{E}, 339\right.$ metres altitude, 2,843 $\mathrm{m}^{2}$ area), a check-dam across the Sarsa River approximately $10 \mathrm{~km}$ upstream from its confluence with the Sawa River.

\begin{tabular}{l} 
Aquatic plant species \\
\hline CHARACEAE \\
- Nitella spp. \\
CYPERACEAE \\
- Scirpus littoralis \\
ELATINACEAE \\
- Bergia ammannioides \\
HYDROCHARITACEAE \\
- Hydrilla verticillata \\
LENTIBULARIACEAE \\
- Utricularia SPp. \\
POTAMOGETONACEAE \\
- Potamogeton crispus \\
- Potamogeton nodosus
\end{tabular}

\section{Other aquatic taxa}

BIRDS

- Black-winged stilt (Himantopus himantopus)

- Common kingfisher (Alcedo atthis)

- Dabchick (Tachybaptus ruficollis)

- Redshank (Tringa totanus)

- Ducks (species unidentified)

- Eurasian collared dove (Streptopelia decaocto)

- Great egret (Ardea alba)

- Grey heron (Ardrea cinerea)

- Indian pond heron (Ardeola grayii)

- Jungle babbler (Turdoides striata)

- Little cormorant (Microcarbo niger)

- Moorhen (Gallinula chloropus)

- Oriental white ibis (Threskiornis melanocephalus), local name 'cordateli'

- Peacock (Pavo cristatus)

- Pied kingfisher (Ceryle rudis)

- Red-wattled plover (Vanellus indicus)

FISH

- Numerous small (up to $2 \mathrm{~cm}$ ) fish, unidentified

\section{ODONATA}

- Bright blue-bodied damselflies (unidentified)

- Dark blue-grey hawker with black tip to abdomen (unidentified)

\section{OTHER INVERTEBRATES}

- Pond skaters (species unidentified)

- Limnaea spp. (non-operculate water snails, species unidentified) 


\section{Tilda (TI): Sarsa catchment}

Tilda $\left(27.188411^{\circ} \mathrm{N}, 76.414071^{\circ} \mathrm{E}, 329\right.$ metres altitude, $5,488 \mathrm{~m}^{2}$ area), a check-dam across the Tilda River upstream of its confluence with the Baghani River, forming a deep, permanent clear-water pool ringed by patera (the local name for Typha angustata), rich in aquatic life and supporting multiple uses including a temple located at the head of the impoundment.

\section{Aquatic plant species}

LENTIBULARIACEAE

- Utricularia spp.

POTAMOGETONACEAE

- Potamogeton crispus

- Potamogeton pectinatus

TYPHACEAE

- Typha angustata (local name 'patera')
Other aquatic taxa BIRDS

- Pied wagtail (Motacilla alba)

- Rock dove (Columba livia)

- Rose-ringed, or ring-necked parakeet (Psittacula krameri)

\section{REPTILES}

- Terrapin (long-necked species, unidentified)

- Python (reported by local people but not observed)

\section{FISHES}

- Systomus sarana (locally known by the generic cyprinid name 'rohu', with a complete lateral line spanning 33 scales, two pairs of fine barbels, dorsal III/8, anal III/5), caught in its black (dark) form but reportedly also present in white and red forms

- Eel (local name 'bam'), reported by locals but not observed

\section{INVERTEBRATES}

- Red darter (small dragonflies, local name used by children 'helicopter')

- Damselfly, unidentified with blue thorax and black abdomen with blue tip

- Damselfly, unidentified with blue thorax and abdomen

- Pond skater, species unidentified

\section{Tehela (TE): Baghani catchment}

Tehela $\left(27.249588^{\circ} \mathrm{N}, 76.441471^{\circ} \mathrm{E}, 344\right.$ metres altitude, $3,699 \mathrm{~m}^{2}$ area), a check dam on the Jalumbragarh river (a tributary of the Baghani system) forming a shallow impoundment supporting extensive stock watering.

\begin{tabular}{|l|l|}
\hline Aquatic plant species & Other aquatic taxa \\
\hline CHARACEAE & BIRDS \\
- Nitella spp. & $\bullet \quad$ Little cormorant (Microcarbo niger) \\
CONVOLVULACEAE & \\
$\begin{array}{l}\text { - Ipomoea carnea (woody alien invasive) } \\
\text { SALVINIACEAE }\end{array}$ & INVERTEBRATES \\
- Azolla pinnata & - Abundant small damselflies with blue \\
& thorax and abdomen, unidentified \\
& - Abundant reddish darters, unidentified \\
& Pond skaters \\
\hline
\end{tabular}


- Abundant water boatmen in the cover of rootlets of emergent Ipomoea carnea

\begin{tabular}{|c|c|}
\hline \multicolumn{2}{|c|}{ Mandalwass, upper impoundment (MAu): Baghani catchment } \\
\hline \multicolumn{2}{|c|}{$\begin{array}{l}\text { Mandalwass, upper impoundment }\left(27.277571^{\circ} \mathrm{N}, 76.33273^{\circ} \mathrm{E}, 496 \text { metres altitude, } 73,514 \mathrm{~m}^{2} \text { area), }\right. \\
\text { a large dam on the headwaters of the Baghani River at the top of a high mountain ridge with } \\
\text { substantial fish stocks for which village people allot contracts to commercial fishermen providing an } \\
\text { annual income used to refurbish the upper and lower Mandalwass dams. }\end{array}$} \\
\hline Aquatic plant species & Other aquatic taxa \\
\hline $\begin{array}{l}\text { - None visible, including in extensive rocky } \\
\text { drawdown areas }\end{array}$ & $\begin{array}{l}\text { BIRDS } \\
\text { - } \quad \text { Asian openbill stork (Anastomus oscitans), } \\
\text { - just two } \\
\text { - } \quad \text { Rabchick (Tachybaptus ruficollis), just one } \\
\text { FISH } \\
\text { - High reported density of fish, but none seen } \\
\text { in turbid water } \\
\text { INVERTEBRATES } \\
\text { - Red darters, unidentified } \\
\text { - Pond skaters, unidentified }\end{array}$ \\
\hline
\end{tabular}

\section{Mandalwass, lower impoundment (MAl): Baghani catchment}

Mandalwass, lower impoundment $\left(27.279707^{\circ} \mathrm{N}, 76.333966^{\circ} \mathrm{E}, 496\right.$ metres altitude, $12,896 \mathrm{~m}^{2}$ area), smaller and shallower impoundment below MAu with well-established, dense vegetation supporting multiple uses including extensive grazing.

\begin{tabular}{|c|c|}
\hline Aquatic plant species & Other aquatic taxa \\
\hline $\begin{array}{l}\text { CYPERACEAE } \\
\text { - Cyperus alopecuroides } \\
\text { GENTIANACEAE } \\
\text { - Nymphoides indica } \\
\text { POTAMOGETONACEAE } \\
\text { - Potamogeton nodosus } \\
\text { - Potamogeton pectinatus } \\
\text { SALVINIACEAE } \\
\text { - Azolla pinnata } \\
\text { TYPHACEAE } \\
\text { - Typha angustata (local name 'patera') }\end{array}$ & $\begin{array}{l}\text { BIRDS } \\
\text { - } \quad \text { Little cormorant (Microcarbo niger) } \\
\text { - } \text { Red-wattled plover (Vanellus indicus) } \\
\text { - } \text { - Indian pond heron (Ardeola grayii) } \\
\text { - } \quad \text { Great egret (Ardea alba) } \\
\text { - } \quad \text { Dabchick (Tachybaptus ruficollis) } \\
\text { - Geese, unidentified } \\
\text { - } \quad \text { Ducks (black with white flash on wings), } \\
\text { - } \quad \text { Enidentified } \\
\text { - } \quad \text { River tern (Sterna aurantia) } \\
\text { HERPTILES } \\
\text { - Frogs (small), unidentified } \\
\text { - Terrapin, unidentified } \\
\text { INSECTS } \\
\text { - Small ('2 } 2 \mathrm{~cm} \text { ) damselfly with blue thorax and } \\
\quad \text { abdomen, unidentified }\end{array}$ \\
\hline
\end{tabular}


- Medium (' $4 \mathrm{~cm}$ ) damselfly with blue thorax and abdomen, unidentified

- Reddish darter, unidentified

- Grey-blue hawker with black tip to abdomen, unidentified

\section{Jabar Sagar (JS): Arvari catchment}

Jabar Sagar $\left(27.207373^{\circ} \mathrm{N}, 76.202331^{\circ} \mathrm{E}, 386\right.$ metres altitude, $1,528 \mathrm{~m}^{2}$ area) is an anicut on the Arvari river serving farmland around Harmeerpur, one of the earliest installed with support from TBS in the late 1980s., surrounded by farmed land up to the water's edge.

\begin{tabular}{|c|c|}
\hline Aquatic plant species & Other aquatic taxa \\
\hline $\begin{array}{l}\text { No plant species found at this site was aquatic, } \\
\text { all terrestrial species invading the drawdown } \\
\text { zone from surrounding farmed land } \\
\text { ASTERACEAE } \\
\text { - Parthenium hysterophorus (erect invasive } \\
\text { alien ruderal composite weed with rocket- } \\
\text { like leaves, from Mexico) } \\
\text { CHENOPODIACEAE } \\
\text { - Chenopodium album } \\
\text { FABACEAE } \\
\text { - Medicago polymorpha } \\
\text { PAPAVERACEAE } \\
\text { - Argemone mexicana (alien invasive species } \\
\text { exploiting the drawdown zone by invasion } \\
\text { from the land) } \\
\text { - POACEAE } \\
\text { POLYGONACEAE } \\
\text { - Polygonum spp., a prostrate, terrestrial } \\
\text { plant with numerous axillary flowers, } \\
\text { exploiting the exposed soils of the } \\
\text { drawdown zone }\end{array}$ & $\begin{array}{l}\text { BIRDS } \\
\text { - } \quad \text { Cattle egret (Bubulcus ibis) } \\
\text { - } \quad \text { Black-winged stilt (Himantopus } \\
\text { - } \text { himantopus) } \\
\text { Red-wattled plover (Vanellus indicus) }\end{array}$ \\
\hline
\end{tabular}

\section{Anicut by Kalid (Kaler) village (KA): Arvari catchment}

Large concrete anicut (a flat dam on low topography land) near Kalid (Kaler) village $\left(27.155427^{\circ} \mathrm{N}\right.$, $76.224163^{\circ} \mathrm{E}, 386$ metres altitude, $27,214 \mathrm{~m}^{2}$ area), downstream of Harmeerpur, retaining a permanent body of water on the Arvari river and heavily used for grazing.

\begin{tabular}{|l|l|}
\hline Aquatic plant species & Other aquatic taxa \\
\hline POTAMOGETONACEAE & BIRDS \\
- Potamogeton crispus & - Little cormorant (Microcarbo niger) \\
- Potamogeton nodosus & - Red-wattled plover (Vanellus indicus) \\
- Potamogeton pectinatus & - Pied kingfisher (Ceryle rudis) \\
HYDROCHARITACEAE & - Cattle egret (Bubulcus ibis) \\
- Vallisneria natans & - Dabchick (Tachybaptus ruficollis) \\
MARSILEACEAE (Pteridophyta) & - Great egret (Ardea alba) \\
- Marsilea minuta & - Redshank (Tringa totanus) \\
& - Pale martin (Riparia diluta) \\
\hline
\end{tabular}




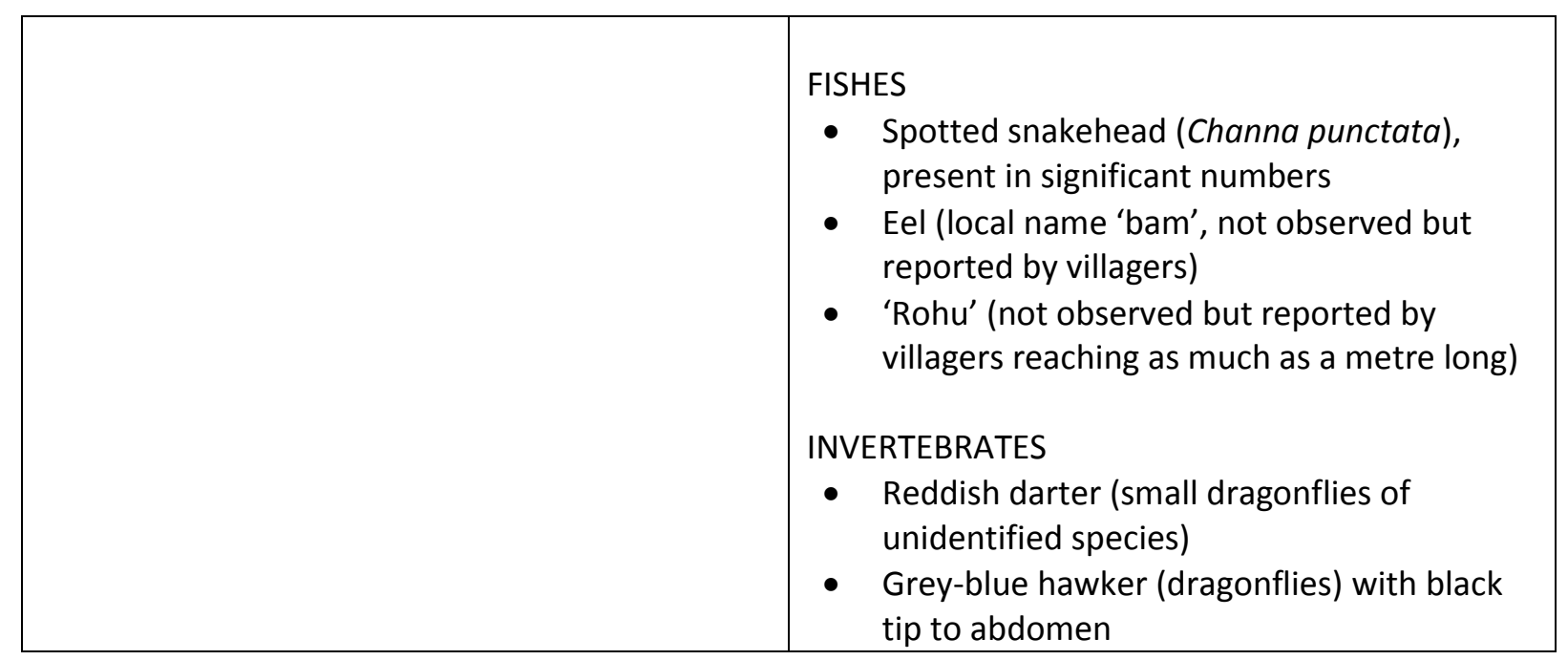

